\title{
粉末パーム油添加大豆蛋白質ゲルのテクスチャー への油脂融点の影響
}

\author{
山野善 正 $^{*}$ 田村成 正 $^{*}$ 三木英三*
}

\section{Effect of Melting Point of Palm Oil on the Texture of Soybean Protein Gel}

\author{
Yoshimasa Yamano*, Shigemasa TAmura* and Eizo Miki* \\ *Department of Bioresource Science, Kagawa University, \\ Ihenobe, Miki-cho, Kagawa, 761-07
}

\begin{abstract}
The effects of melting point of palm oil on the gel formation from the soybean protein and on the texture of the gel were investigated. Hardness of the gels containing high melting point palm oils $\left(33^{\circ}\right.$ and $\left.40^{\circ} \mathrm{C}\right)$ increased with an increase of the oil content, but that of the gel containing low melting point oil $\left(21^{\circ} \mathrm{C}\right)$ decreased with the oil content. Water holding capacity of all gels increased linearly proportional to oil content and the larger increasing ratio was observed for the gels containing higher melting point oil. Gelling rates of all gels decreased with an increase of the oil content, but the difference in the rate was not clear among the gels. Larger the oil content, the increasing rate of viscosity of each soy milk during heating at $50^{\circ} \mathrm{C}$ was lower, but its maximum viscosity value was larger. There was no difference among the maximum viscosity values of the soy milks concerning melting point of oils. Almost all oils were incorporated into gels up to the content of $15 \%$. The electron microscopic observation revealed that oil seems to bind with protein weakly or to float in the network of protein as oil droplets of 7 to $10 \mu \mathrm{m}$ in diameter, and that the oil droplets of the samples containing higher melting point oils appear to be smaller than those of the samples containing lower melting point oils.

(Received June. 9, 1986)
\end{abstract}

大豆蛋白質-油一水系ゲルのテクスチャーとゲル形成に ついては，すでに報告しておりり，その研究に用いた粉 林パーム油を添加することにより，ゲルの硬さは，油脂 添加量に対し，ほぼ淔線的に増大することを示した．用 いた油脂の融点は，約 $33^{\circ} \mathrm{C}$ であり，油脂添加によるゲ ルの硬さの增大は，油脂の粉末化による良好な乳化に基 ブくことが考えられたが，油脂の重要な物性である融点 が大きく変わると，ゲルのテクスチャ一屯変化すること が予想される．そこで，本研究では，油脂の重要な物性 である融点が，この複雑な系においてどのような効果を 及ぼすか，特にテクスチャ一の面からそれを検討し，更 に袖脂融点の相違によるゲルのテクスチャーの自由な゙調 整の可能性をみるために融点の異なる 3 種類のパーム油
を粉末化したすのを添加したゲルを調製して，そのテク スチャーとゲルの形成について検討したので, その結果 を報告する。

\section{実 験 方 法}

\section{1. 試 料}

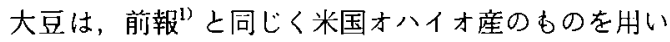
た。粉末油脂は，前報”之同じく $70 \%$ のパーム油を含 んでいるが, $21^{\circ}, 33^{\circ}, 40^{\circ} \mathrm{C}$ (融点の測定は, DSC 法 による）の融点をもつものを使用した．

\section{2. ゲルの調製と硬さ，保水力の測定}

ゲルの調製は，前報”の通り，絹ごし豆腐の製造法に 準じ，凝固剂としてグルコノデルタラクトン（藤沢薬品

\footnotetext{
* 香川大学農学部生物資源科学科（T 761-07 香川県木田郡三木町池戸 2393）
} 
上業(株)）を $0.5 \%$ 添加し, 加熱温度及び時問は $85^{\circ} \mathrm{C}$, 40 分とした。

硬さも前報1 と同じく，富士理科工業製レオメーター （R-UDA）により $25^{\circ} \mathrm{C}$ に保った試料を厚さ $10 \mathrm{~mm}$ に 切った試料につき直ちに測定した，保水力は，前報と同 じくSAIO ら ${ }^{3)}$ の方法に準じ，遠心分離（日立 $18 \mathrm{PR,}$ $3000 \mathrm{rpm} .20$ 分) に上る分離水量の測定によった。本 来, 試料の複雑な構成からくる測定誤差を補偵するため に，各実験は数回繰り这し平均值をとった。

\section{3. 凝固率之粘度変化の測定}

凝固速度を比較するために，豆乳を $85^{\circ} \mathrm{C}$ で加熱凝固 させながら，上述の方法（レオメーター法）により硬さ の変化を測定し，最終の硬さに対する比を求め，凝固率 としだ.

既報1)でも示したように，ゲル形成に関与するタンパ ク質のネットワーク形成による粘度変化をみるために， 加熱によりすぐゲルを形成する温度 $\left(85^{\circ} \mathrm{C}\right)$ ではなく， 徐々にタンパク質の構造变化を起すと考えられる $50^{\circ} \mathrm{C}$ に抢ける豆乳の粘度变化を経時的に $\mathrm{BH}$ 型粘度計（東 京計器(株)）を用いて測定した。

\section{4. 油脂取り込み量の測定}

ゲルを乾燥させ，粉砕後，石油エーテルによるンック スレー抽出法により油脂量を測定し，添加油脂量に対す る割合を求め,ゲル中への油脂の取り込み摔とした22.

\section{5. ゲルの微細構造の観察}

GILL らの臨界点乾燥法 ${ }^{4)-6)}$ に準じた，すなわち，約 2 $\mathrm{mm}^{2}$ 的の大きさに細断したゲルをグルタルアルデヒド 固定液に浸して 2 時閒前固定し，次に，リン酸㣪衝液 （pH 7.2）山で洗浄した．この試料を1\%オスミウム酸 固定液により後固定し，50，70，90，95，100\%のアセ トンにより脱水を行ない，臨界点乾燥した。この乾燥試 料を制断し金蒸着して，切断面及び割断面を明石製作所 製の企查型電子顕微鏡 MSM-4 S に上り加速電圧 $10 \mathrm{kV}$ で観察した。

\section{結果及ひ考察}

\section{1. テクスチャーの変化}

粉木油脂添加量に対する硬さの变化（油脂無添加試料 の硬さを 1 とする）への油脂融点の影響を Fig. 1 に示 した．これによると，どの試料も油脂添加量に対してほ ぼ直線的に変化し, 融点 $40^{\circ} \mathrm{C}$ 及び $33^{\circ} \mathrm{C}$ の試料では硬さ は，油脂添加量とともに増大，また $21^{\circ} \mathrm{C}$ の試料では低 下した，融点が $21^{\circ} \mathrm{C}$ と $33^{\circ} \mathrm{C}$ の間に，この硬さの增大と 低下の傾向の境界が存在するものと推定される。また，
この $21^{\circ} \mathrm{C}$ の武料の結果は，常温で液体の油脂の添加は ゲルの硬さを低下させるという植物油脂での結果" 2 と同 じである．ゲル中では，油脂は一種の乳化状態にあると 考えられるが，油脂の融点の高い試料では，高融点の原 因となる脂肪酸の不飽和部分の少ない（脂肪酸部分の䠅 水性が高い）ことが，エマルションとしての油滴中での

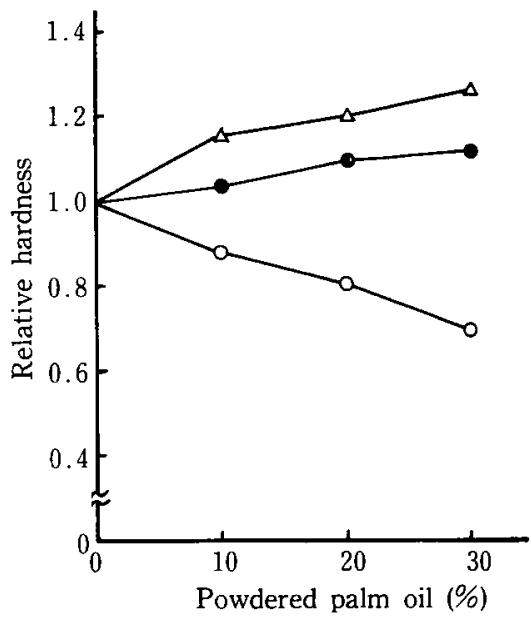

Fig. 1 Effect of melting point of palm oil on the hardness of soybean protein gel

$\left(\bigcirc: 21^{\circ}, \bullet: 33^{\circ}, \triangle: 40^{\circ} \mathrm{C}\right)$

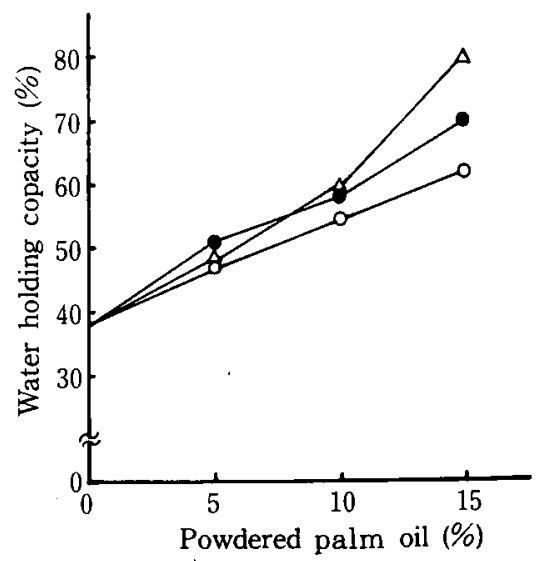

Fig. 2 Effect of melting point of palm oil on the water holding capacity of soybean protein gel

The symbols are the same as in Fig. 1. 
油分子の配列の上で，その構造を硬くしているか，ある いは，油の粒子の，全体として単に固体的倠体的加と いう物理的な硬さが，全体としての硬さに直接影響して いると推察される。

同じく，保水力の変化を Fig. 2 に示した．保水力は， 油脂量とともに，ほぼ直線的に増大するが融点の高いも

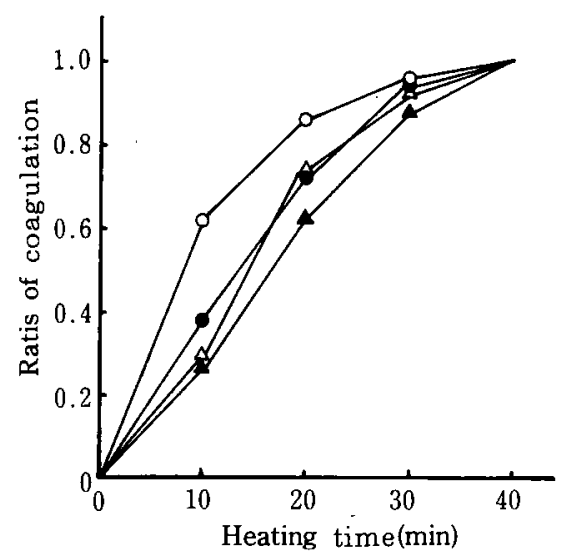

Fig. 3 Coagulating rate of soy milk with the palm oil of melting point of $21^{\circ} \mathrm{C}$

Amount of powdered palm oil added are 0 $(\bigcirc), 4(\bullet), 8(\triangle)$, and $12 \%(\Delta)$.

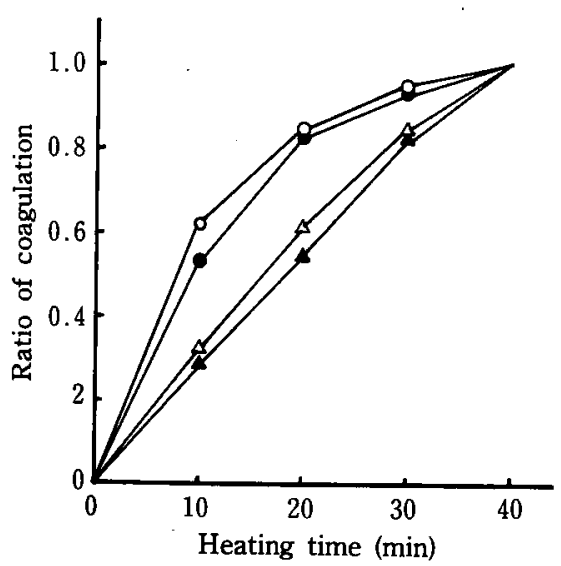

Fig. 4 Coagulating rate of soy milk with the palm oil of melting point of $33^{\circ} \mathrm{C}$

The symbols are the same as in Fig. 3.
のほよ゙，その増大率は高い。この結果，油脂は保水力を 增大させるという以前に得られた結果 ${ }^{2)}$ と同じで，やは り添加量の増加によって硬さを增大させる，あるいは， 低下させるという油脂の種類に加からす⿹，油脂の添加 は，ゲルの保水力を增大させるということがわかる。

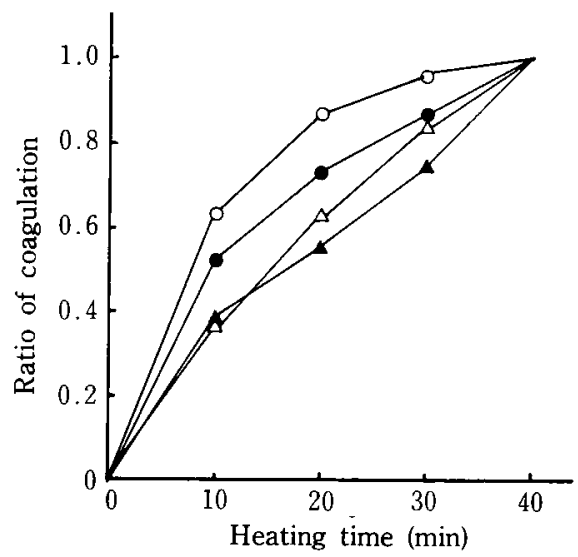

Fig. 5 Coagulating rate of soy milk with the palm oil of melting point of $40^{\circ} \mathrm{C}$

The symbols are the same as in Fig. 3.

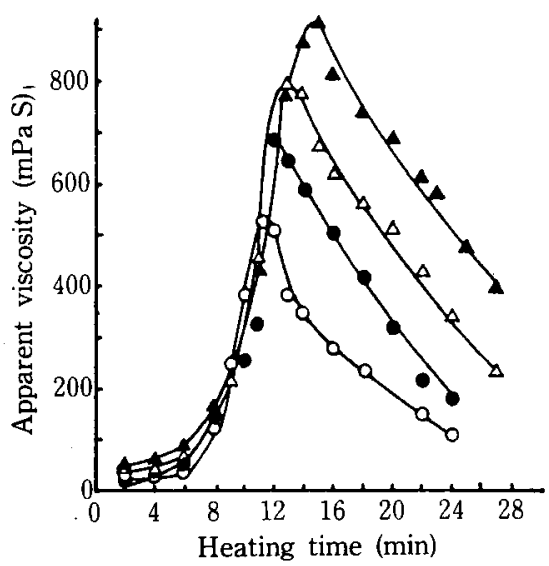

Fig. 6 Viscosity changes of soy milks containing powdered palm oils of melting point of $21^{\circ} \mathrm{C}$ during heating at $25^{\circ} \mathrm{C}$

Contents of palm oils; $\bigcirc: 0, \bullet: 4, \triangle: 8$, A : $12 \%$ 


\section{2. 凝固速度と粘度変化}

3 種類の油脂試料についての凝固率の変化を融点の低 いちから Fig. 3，4及び5にそれぞれ示した。 いずれ の融点の試料においても，油脂添加量が増加すると凝固 速度が遅くなり，これは以前に得られた結果”と同じ傾 向である，融点による凝固速度の違いは，明確には認め がたい，油脂粒子の物理的な硬さそのものが，ゲルの硬 さに影響しているとすれば，この実験の場合，全ての测

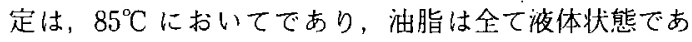

るので物理的な硬さとしては差が表われないと言うこと が，この結果を導いたと考えられる。

3 種の異なる融点の油脂を添加した豆乳の粘度変化を Fig. 6，7 及び 8 に示した. どの豆乳においても粉末油 脂添加量の増加とともに最高粘度の值が上昇し，また， 最高粘度に達する時間が遅くなることが認められ，この 結果は，以前に得られた結果 ${ }^{188)}$ 之同様である，すなわ ち，油脂の添加により，蛋白質の網状構造の形成は遅れ る，あるいは，蛋白質による網状構造が形成しにくくな

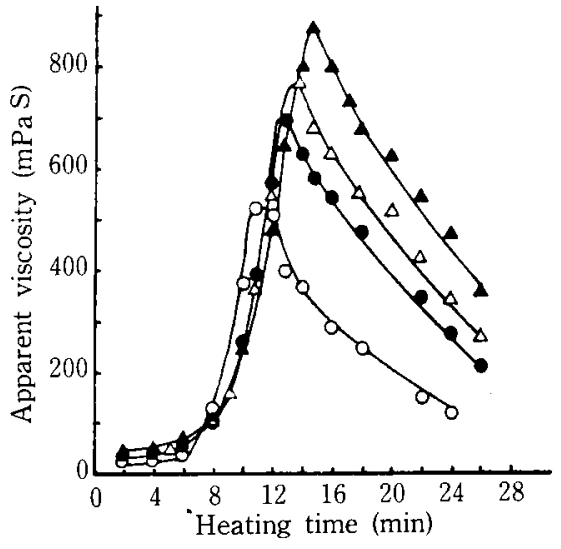

Fig. 7 Viscosity changes of soy milks with the oil of melting point of $33^{\circ} \mathrm{C}$

The symbols are the same as in Fig. 6.

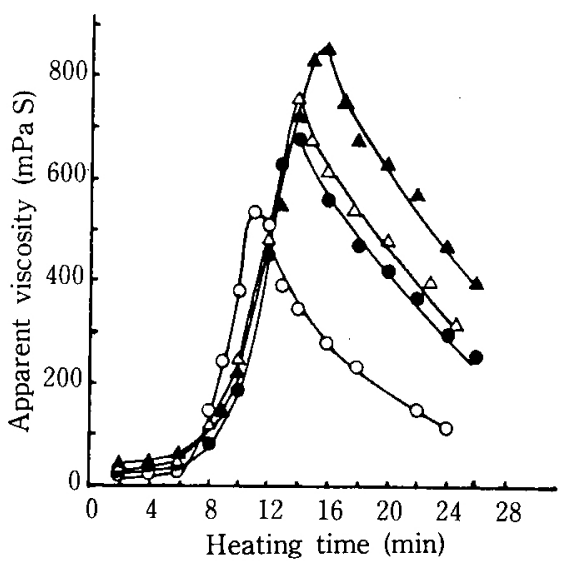

Fig. 8 Viscosity changes of soy milks with the oil of melting point of $40^{\circ} \mathrm{C}$

The symbols are the same as in Fig. 6.
Table 1 Incorporation of palm oil into soybean protein gel

\begin{tabular}{|c|c|c|}
\hline \multicolumn{2}{|c|}{ Added palm oil powder } & \multirow[b]{2}{*}{ Incorporation( $(\%)$} \\
\hline $\begin{array}{l}\text { Melting } \\
\text { point }(\%)\end{array}$ & Content $(\%)$ & \\
\hline \multirow{3}{*}{21} & 10 & 101.5 \\
\hline & 15 & 101.8 \\
\hline & 20 & 97.6 \\
\hline \multirow{3}{*}{33} & 10 & 99.6 \\
\hline & 15 & 101.6 \\
\hline & 20 & 100.6 \\
\hline \multirow{3}{*}{40} & 10 & 99.0 \\
\hline & 15 & 98.3 \\
\hline & 20 & 98.6 \\
\hline
\end{tabular}

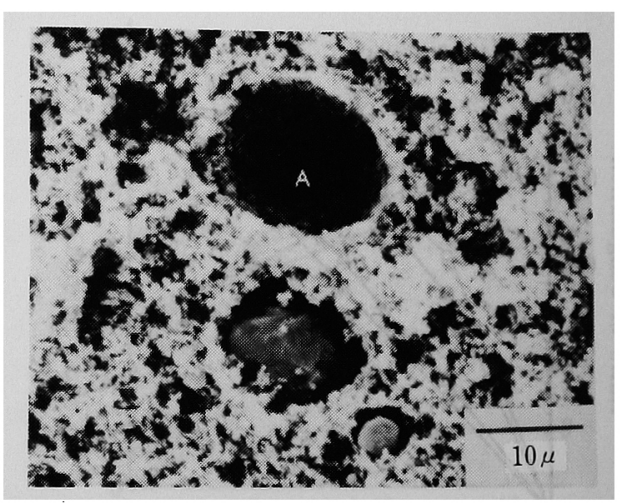

Fig. 9 Electron miscroscopic photograph of the surface of oil added soybean protein gel.

$20 \%$ of powdered palm oil of melting point of $33^{\circ} \mathrm{C}$ was added. Multiplication is 2000. A shows the hole of an oil droplet formed by solvent processing. 


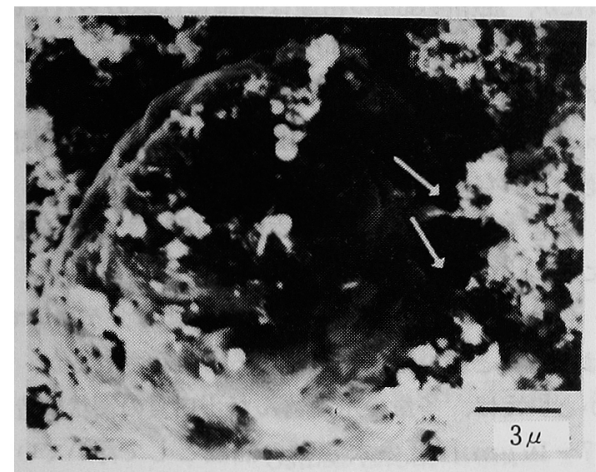

Fig. 10 Electron microscopic photograph of the inner part of the gel shown in Fig. 9.

Multiplication is 5000 . Weak bridges are observed between the oil droplet and protein network $(\rightarrow)$.

るため粘度の上昇が遅れるが，油脂の量が多いと乳化し た油滴の量が増えるため摩擦抵抗が大きくなり，結果と して高い粘度を示すすのと考えられる。

融点の差により粘度の高さには，ほとんど变化がみら れず，これは，凝固率の結果と対応している。

\section{3. 油脂の取り込み}

Table 1 に各試料における油脂の取り込み率を示し た. 実験誤差と考えられる理由で $100 \%$ を超える值む見 られるが，どの油脂を加えたゲルにおいてす粉末油脂添 加量 $15 \%$ まで，ほぼ完全に油脂が取り込まれるとみな せる．この結果あ以前に得られた結果 ${ }^{12)}$ と同じである.

\section{4. ゲルの電子顕微鏡観察}

融点 $33^{\circ} \mathrm{C}$ の油脂を $20 \%$ 加えたゲルの表面及び内部の 電子顕微鏡写真を Fig. 9 及び 10 に示した，油粒子の 大きさは以前に報告したように2)，光学顕微鏡でみたと ころ本来，大豆中に含まれているもので，直径が 2 5 $\mu \mathrm{m}$ ，あとで添加したもので 25〜30 $\mu \mathrm{m}$ であり，また 後に示すように電子顕微鏡でみても両方の油を併せて考 えてすその平均的な直径は $10 \mu \mathrm{m}$ 程度とみられるが, この Fig. 9，10では，粒子の状態をわかりやすく示す ために，やや大き目のものを示した．Fig. 9 によると 前処理により油の粒子がぬけた跡（A）がみられ，その 大きさは，ほぼ 7〜10 $\mu \mathrm{m}$ と考えられる。このような 空腔は，油脂無添加ゲルに扔いては観察されていない。 内部（Fig. 10）には，纎維状の蛋白質と油粒子がその

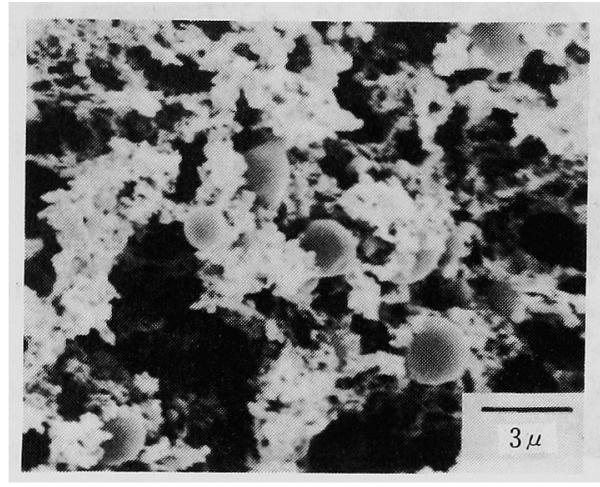

Fig. 11 Oil droplets in the protein gel structure with the oil of melting point of $21^{\circ} \mathrm{C}$

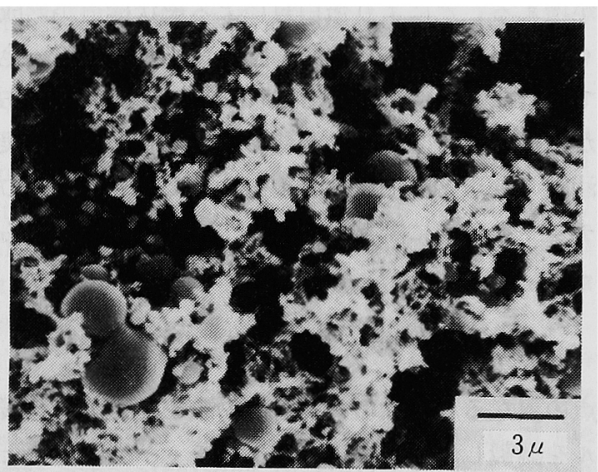

Fig. 12 Oil droplets in the protein gel structure with the oil of melting point of $33^{\circ} \mathrm{C}$

表面の所々でからんでいる状態（Fig. 10 では，矢印で 示したように在の方に 2 本程，粒子から腕が出ているよ うに見える）が観察され，䖪白質一油の間には，極性油 脂が関与した比較的弱い結合が存在し，全体としてみる と，蛋白質の網状構造中に油滴が入り込み，水の中に浮 いているような状態にあると考えられる。

次に， 3 種類の油脂 $20 \%$ 添加試料によるゲルの内部 構造の電子顕微鏡写真を Fig. 11，12 及び 13 に示した。 油脂の融点により蛋白質の結合状態及び油脂の取り込ま れ方にほとんど相違はみられないが，油脂の融点の高い 試料ほよ゙粒子がやや小さくなる傾向がみられる。この結 果, 油脂の融点が高い程ゲルは硬くなるという現象と, 


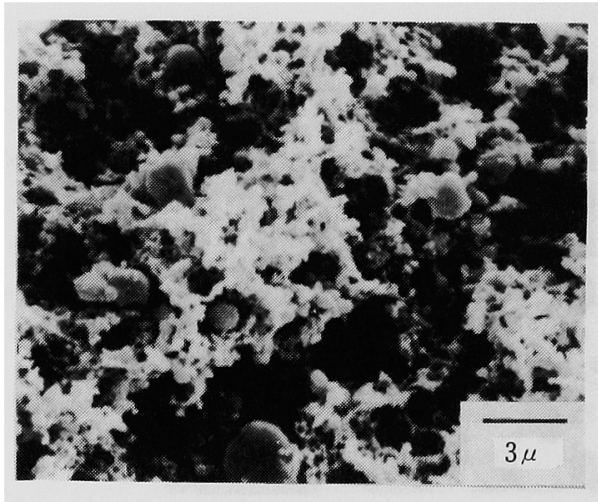

Fig. 13 Oil droplets in the protein gel structure with the oil of melting point of $40^{\circ} \mathrm{C}$

油脂が増えることにより蛋白質による網状構造が形成し にくくなるかも知れないが，油脂の粒子が小さく，全体 として維密なゲルを形成することには，相関関係がある ことが推察される，また，既報の結果と本報告の結果か ら，油脂の融点と添加量を変えることにより，ゲルのテ クスチャーを自由に調整することができることが明らか になった。

\section{要 約}

融点の異なる 3 種類のパーム油粉末を加えて大豆蛋白 質ゲルを調製し，ゲル形成とテクスチャーを調べたとこ ろ, 次の結果が得られた。

（1）融点の高い油（ $33^{\circ} \mathrm{C}$ 及び $40^{\circ} \mathrm{C} ）$ を加えたゲルの 硬さは，添加油脂量とともに増大するが，融点の低い油 $\left(21^{\circ} \mathrm{C}\right)$ を加えだ試料では油脂量とともに硬さは低下し た. 保水力は, どの油脂のゲルでも油脂量とともにほぼ 直線的に增大し，融点の高いもの程, 増大率が大きかっ た。

（2）いずれの試料でも，油脂量とともに凝固速度が遅
くなったが，油脂種類間の相違は明確には認められない。 $50^{\circ} \mathrm{C}$ で加熱した豆乳の粘度上昇は油脂量が多いほど， 遅いが，最高粘度の值は多い油脂量の場合の方がむしろ 高かった. 粘度の高さは, 凝固速度と同じく, 油脂間に 差は認められなかった。

（3）いずれの油脂でも油脂添加量 $15 \%$ までは，ほぼ 完全にゲル中に油脂が取り込まれた。

（4）油脂添加ゲルの電子顕微鏡観察により，ゲル中で， 油滴は蛋白質と弱い結合をしていると推定されるが, ど ちらかといえば，多量の水を含んだ蛋白質の網状構造の 中に 7〜 $10 \mu \mathrm{m}$ 程度の大きさの油滴として浮いている と考えられる、融点による油滴の状態に余り差はみられ ないが，融点の高い試料ほよ゙やや油滴が小さくなる㑯向 がみられた。

この研究に要した費用の一部は, 昭和 58 年度文部省 特定研究経費により支出された. また， 3 種類の粉末油 脂を提供していただいた，日本油脂 (侏)に樑謝致します，

\section{文献}

1) 山野善三・三木英三・福井義明 : 日食工誌，28, 131 (1981).

2）山野善三・三木英三・福井義明 : 日食工誌，28, 136 (1981).

3) Saio, K. and Watanabe, T. : Agric. Biol. Chem., 33, 301 (1969).

4) Gill, T.A. and Tung, M.A. : J. Food Sci., 43, 1481 (1978).

5) 藤野吉世 - 塚田扶美子 - 益本美千代 - 長谷川喜代 三:農化, 55, 333 (1981)

6) 赤羽ひろ - 小林三智子・中浜信子 : 家政誌, 32 , 426 (1981).

7) 中山幸子 - 山野善正: 日食工誌，30，658 (1983).

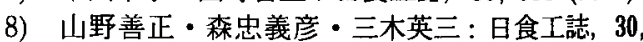
552 (1983).

（昭和 61 年 6 月 9 日受理） 